\title{
Pengaruh Model Pembelajaran Concept Sentence Berbantu Media Puzzle Terhadap Keterampilan Menulis Siswa
}

\author{
Faradiba Polisiandani ${ }^{1}$, Mudzanatun ${ }^{2}$, Prasena Arisyanto ${ }^{3}$ \\ 1,2,3 Jurusan PGSD, Universitas PGRI, Semarang, \\ e-mail: faradibapolisiandani@gmail.com
}

\begin{abstract}
ABSTRAK
Penelitian ini bertujuan untuk mengetahui pengaruh model pembelajaran Concept Sentence berbantu media Puzzle terhadap keterampilan menulis karangan narasi siswa kelas IV SD Negeri Peterongan. Penelitian ini menggunakan metode penelitian kuantitatif, dan desain penelitian PreExperimental Designs (nondesigns) dalam bentuk One-Group Pretest-Posttest Design. Karena terdapat pretest sebelum diberikan perlakuan, yang selanjutnya diberikan perlakuan yaitu pembelajaran dengan menggunakan model pembelajaran Concept Sentence, kemudian dilakukan posttest. Variabel independen pada penelitian ini adalah model pembelajaran Concept Sentence, yang dilambangkan dengan " $X$ ". Variabel dependen pada penelitian ini adalah keterampilan menulis siswa, yang dilambangkan dengan "Y". Sampel dalam penelitian ini adalah seluruh kelas IV SD Negeri Peterongan yang berjumlah 30 siswa. Pada penelitian ini teknik sampling yang digunakan adalah Nonprobability Sampling karena semua anggota populasi dipilih menjadi sampel.teknik pengambilan data pada penelitian ini adalah dengan wawancara, observasi, tes, dan studi dokumentasi. Hasil penelitian menunjukkan bahwa nilai Posttest lebih tinggi dari Pretest maka dapat disimpulkan bahwa Penggunaan model pembelajaran Concept Sentence berbantu media puzzle dapat meningkatkan keterampilan menulis siswa kelas IV SD Negeri Peterongan tahun pelajaran gasal 2018/2019.
\end{abstract}

Kata Kunci: Concept Sentence, Karangan Narasi, Keterampilan Menulis, Media Puzzle.

\section{ABSTRACT}

This study aims to determine the effect of the Concept Sentence learning model supported by Puzzle media on the narrative essay writing skills of fourth grade students of SD Negeri Peterongan. This research uses quantitative research methods, and Pre-Experimental Designs (nondesigns) research designs in the form of One-Group Pretest-Posttest Design. Because there is a pretest before being given treatment, which is then given a treatment that is learning using the Concept Sentence learning model, then posttest. The independent variable in this study is the Concept Sentence learning model, which is symbolized by " $X "$ ". The dependent variable in this study is student writing skills, which are denoted by "Y". The sample in this study were all class IV of SD Peterongan Elementary School which numbered 30 students. In this study the sampling technique used was Nonprobability Sampling because all members of the population were selected as samples. The data collection techniques in this study were interviews, observations, tests, and documentation studies.

The results of the treatment can be known more accurately, because it can compare with the situation before being treated. By obtaining a higher posttest value than the pretest, it can be concluded that the use of the Concept Sentence learning model assisted by media puzzles can improve the writing skills of fourth grade students in the State Elementary School of Peterongan for odd lessons in 2018/2019.

Keywords: Concept Sentence, Narrative Essence, Writing Skills, Puzzle. 


\section{Pendahuluan}

Berdasarkan Undang-Undang Sistem Pendidikan Nasional Nomor 20 Tahun 2003 Bab 1 Pasal 1 No.1 yang berbunyi:

"Pendidikan adalah usaha sadar dan terencana untuk mewujudkan suasana belajar dan proses pembelajaran agar peserta didik secara aktif mengembangkan potensi dirinya untuk memiliki kekuatan spiritual keagamaan, pengendalian diri, kepribadian, kecerdasan, akhlak mulia, serta keterampilan yang diperlukan dirinya, masyarakat, bangsa dan negara."

Pendidikan merupakan suatu tindakan yang mempunyai peran penting dalam perkembangan dan kemajuan manusia, karena pendidikan dapat menciptakan manusia berkualitas yang memiliki pengetahuan, wawasan luas, keterampilan, dan berkarakter. Dengan begitu untuk mencapai tujuan pendidikan diperlukan bahasa nasional yang dapat digunakan sebagai pemersatu bangsa Indonesia yang berbeda bahasa, suku, adat, dan budaya yaitu bahasa Indonesia. Sehingga bahasa Indonesia digunakan sebagai alat komunikasi berupa lisan dan tulisan dalam bidang pendidikan, serta menjadi salah satu mata pelajaran wajib yang ada di sekolah.

Menurut Departemen Pendidikan dan Kebudayaan, mata pelajaran bahasa Indonesia berfungsi untuk mengembangkan kemampuan bernalar, berkomunikasi, mengungkapkan pikiran dan perasaan, serta membina kesatuan dan persatuan bangsa (Sumardi, 2000: 32). Pembelajaran bahasa Indonesia bertujuan untuk meningkatkan kemampuan siswa dalam berkomunikasi dengan bahasa Indonesia baik secara lisan maupun tertulis.

Tarigan (2008: 1) mengemukakan bahwa "keterampilan berbahasa mempunyai empat komponen, yaitu (1) keterampilan menyimak (listening skills), (2) keterampilan berbicara (speaking skills), (3) keterampilan membaca (reading skills), dan (4) keterampilan menulis (writing skills)." Keempat komponen ini saling berkaitan satu sama lain, sehingga diharapkan siswa mampu menguasai keempat komponen tersebut agar terampil dalam menggunakan bahasa Indonesia yang baik dan benar.

Penelitian ini membahas salah satu komponen yaitu keterampilan menulis. Seperti yang diungkapkan oleh Nurgiyantoro (2012: 422) mengenai keterampilan menulis sebagai berikut:

Aktivitas menulis merupakan suatu bentuk manifestasi kompetensi berbahasa paling akhir dikuasai pembelajar bahasa setelah kompetensi mendengarkan, berbicara, dan membaca. Dibanding tiga kompetensi berbahasa yang lain, kompetensi menulis secara umum boleh dikatakan lebih sulit dikuasai bahkan oleh penutur asli bahasa yang bersangkutan sekalipun. Hal itu disebabkan kompetensi menulis menghendaki penguasaan berbagai unsur kebahasaan dan unsur di luar bahasa itu sendiri yang akan menjadi isi karangan. Baik unsur bahasa maupun unsur isi pesan harus terjalin sedemikian rupa sehingga menghasilkan karangan yang runtut, padu, dan berisi.

Menulis seringkali dianggap sebagai bentuk keterampilan berbahasa yang mudah. Akan tetapi berdasarkan pada realita yang ada, keterampilan menulis yang dimiliki setiap individu cenderung paling rendah apabila dibandingkan dengan keterampilan berbahasa yang lain. Menulis karangan merupakan salah satu materi pembelajaran keterampilan menulis yang diberikan pada tingkat Sekolah Dasar. Salah satu contoh karangan yang diajarkan di Sekolah Dasar adalah karangan narasi.

Agar mengetahui kemampuan siswa dalam membuat karangan narasi yang baik dan benar, pembelajaran menulis karangan narasi dilaksanakan oleh guru kepada siswa kelas IV Sekolah Dasar. Usia kelas IV Sekolah Dasar berada pada tahap operasional kongkrit sehingga siswa lebih mudah menangkap materi pelajaran melalui benda-benda nyata. Salah satu Kompetensi Dasar yang harus dikuasai siswa kelas IV Sekolah Dasar adalah menulis karangan narasi tentang Perjuangan Para Pahlawan menggunakan bahasa sendiri dengan memperhatikan pilihan kata dan ejaan yang benar. Namun pada kenyataannya siswa kelas IV Sekolah Dasar mempunyai minat dan motivasi yang kurang dalam menulis karangan narasi.

Berdasarkan hasil wawancara dengan Bapak Arifin S.Pd selaku guru kelas IV SD Negeri Peterongan, diperoleh informasi bahwa keterampilan menulis karangan mata 
pelajaran Bahasa Indonesia masih rendah, sebagian siswa belum mencapai Kriteria Ketuntasan Minimal (KKM). Untuk KKM mata pelajaran Bahasa Indonesia di SD Negeri Peterongan yaitu 70. Ketika diberikan tugas untuk menulis karangan, siswa hanya menulis karangan seadanya, bahkan ada siswa yang hanya mampu menuliskan beberapa kalimat saja. Dengan demikian dapat diketahui bahwa minat menulis siswa masih rendah dan siswa mengalami kesulitan dalam menemukan ide dan menuangkan gagasan ke dalam bentuk tulisan.

Rendahnya keterampilan menulis karangan tersebut disebabkan karena pada saat proses pembelajaran berlangsung penggunaan media pembelajaran yang bervariasi dan menarik belum dilaksanakan pada proses pembelajaran sehingga siswa merasa cepat bosan dengan materi yang diajarkan karena siswa hanya duduk dan mendengarkan penjelasan guru. Kurangnya partisipasi aktif siswa dalam kelas menyebabkan kurangnya minat dan motivasi dalam menulis karangan, dengan begitu siswa merasa kesulitan untuk menemukan ide dan menuangkan gagasan ke dalam bentuk tulisan

Berdasarkan uraian permasalahan diatas, peneliti berupaya melakukan penelitian dengan cara menggunakan model pembelajaran yang menarik dan efektif, menggunakan media pembelajaran yang bervariasi dan sesuai dengan materi pelajaran, serta memanfaatkan sarana dan prasarana yang ada di sekolah secara optimal. Dengan demikian dapat ditetapkan tujuan penelitian ini adalah untuk mengetahui pengaruh model pembelajaran Concept Sentence berbantu media Puzzle terhadap keterampilan menulis karangan narasi siswa kelas IV SD Negeri Peterongan

Penelitian ini mengkaji mengenai model pembelajaran Concept Sentence dibantu dengan media pembelajaran Puzzle. Media Puzzle ini berupa kepingan-kepingan gambar yang dapat disusun hingga terbentuk gambar utuh. Media ini dapat meningkatkan daya ingat, berfikir kritis, dan keaktifan. Media ini akan membantu siswa dalam memperoleh gambaran tentang objek yang akan ditulis dalam karangan.

\section{Metode}

Penelitian ini dilaksanakan pada bulan November 2018 Di SD Negeri Peterongan Kota Semarang. Pada penelitian ini metode penelitian yang digunakan adalah penelitian kuantitatif. Metode penelitian kuantitatif dapat diartikan sebagai metode penelitian yang digunakan untuk meneliti populasi atau sampe, teknik pengambilan sampel pada umumnya dilakukan secara random, pengumpulan data menggunakan instrumen penelitian, analisis data bersifat statistik (Sugiyono, 2017: 13).

Sampel dalam penelitian ini adalah seluruh kelas IV SD Negeri Peterongan yang berjumlah 30 siswa. Penelitian ini menggunakan teknik Nonprobability Sampling karena semua anggota populasi dipilih menjadi sampel.

Penelitian ini menggunakan desain penelitian Pre-Experimental Designs (nondesigns) dalam bentuk One-Group Pretest-Posttest Design. Karena terdapat pretest sebelum diberikan perlakuan, yang selanjutnya diberikan perlakuan yaitu pembelajaran dengan menggunakan model pembelajaran Concept Sentence, kemudian dilakukan posttest. Dengan demikian hasil perlakuan dapat diketahui lebih akurat, karena dapat membandingkan dengan keadaan sebelum diberi perlakuan. Desain ini dapat digambarkan seperti berikut:

\section{$\mathrm{O}_{1} \times \mathrm{O}_{2}$}

\section{Keterangan:}

$\mathrm{O} 1$ = Nilai pretest (sebelum diberi perlakuan) yang dilakukan satu kali untuk mengukur variabel terikat

O2 = Nilai posttest (setelah diberi perlakuan) yang dilakukan satu kali untuk mengukur variabel bebas.

$\mathrm{X}=$ Perlakuan (treatment). Dilakukan dengan 
Menggunakan model pembelajaran Concept Sentence berbantu media puzzle pada pembelajaran Kelas IV Tema 5 Pahlawanku Subtema 1 Perjuangan Para Pahlawan. (Sugiyono, 2017: 111). Teknik pengumpulan data yang digunakan dalam penelitian ini yaitu 1) wawancara, Sebelum melakukan wawancara peneliti menyiapkan instrumen wawancara yang berisi pertanyaan atau pernyataan yang meminta dijawab oleh responden berkenaan dengan fokus masalah atau variabel-variabel yang dikaji. 2) Observasi, Pencatatan observasi dilakukan dengan membuat deskripsi singkat berkenaan dengan perilaku dan kegiatan yang diamati. 3) Tes, dilakukan tes sebanyak dua kali yaitu pretest (sebelum diberi perlakuan) dan posttest (setelah diberi perlakuan).

Uji analisis data dalam penelitian ini menggunakan: 1) uji normalitas untuk mengetahui sampel dari populasi berdistribusi normal atau tidak (Sudjana, 2005: 466), 2) Uji Banding Pretest dan Posttest untuk mengetahui signifikansi perbedaan rata-rata nilai Pretest dan Posttest yang diperhitungan sebelumnya menunjukkan berdistribusi normal, 3) uji hipotesis digunakan untuk membuktikan ada pengaruh atau tidak ada pengaruh model pembelajaran Concept Sentence berbantu media puzzle terhadap keterampilan menulis karangan narasi siswa kelas IV SD Negeri Peterongan.

\section{Hasil dan Pembahasan}

Penelitian ini dilaksanakan pada bulan November 2018 di SD Negeri Peterongan. SD Negeri Peterongan terletak di Jalan Kompol Maksum Nomor 292, Peterongan, Semarang Selatan, kota Semarang Jawa Tengah 50242. Sebelah utara SD N Peterongan adalah UPTD, kemudian di sebelah selatan ada TK PGRI, sebelah timur ada SMK 9 Semarang dan sebelah barat ada jalan raya.

Penelitian ini hanya dilaksanakan pada kelas IV tahun pelajaran 2018/2019 dengan jumlah 30 siswa. Siswa kelas IV SD Negeri Peterongan memiliki budaya disiplin dan tertib yang baik, dibuktikan dengan tidak adanya siswa kelas IV yang terlambat masuk kelas dan selalu memakai atribut yang lengkap. siswa berpakaian bersih, rapi dan sopan.

Waktu pembelajaran berlangsung, siswa menjaga ketenangan didalam kelas. Siswa selalu meminta izin kepada guru kelas atau kepala sekolah jika meninggalkan sekolah sebelum waktu pembelajaran selesai. Siswa kelas IV SD Negeri Peterongan tidak malu menunjukkan potensi diri yang dimiliki seperti berani menunjuk diri sendiri untuk maju ke depan mempresentasikan hasil kerjanya atau untuk membaca naskah yang diminta guru.

Proses pembelajaran di kelas IV masih menggunakan konsep pembelajaran Teacher Center, hal ini membuat siswa kurang aktif dalam proses kegiatan belajar mengajar. Guru kelas IV SD Negeri Peterongan kurang melakukan inovasi, karena kegiatan belajar mengajar yang berlangsung masih sering menggunakan metode ceramah, belum diterapkannya model pembelajaran yang variatif. Dalam kegiatan belajar mengajar di kelas IV SD Negeri Peterongan, guru juga belum menggunakan media pembelajaran yang interaktif. Sehingga siswa merasa cepat bosan dengan materi yang diajarkan oleh guru. Fokus belajar siswa cenderung teralihkan ke yang lain seperti mengobrol dengan teman atau bermain dengan teman. Hal ini tentu mempengaruhi prestasi belajar siswa kelas IV SD Negeri Peterongan.

Penelitian ini mengkaji satu mata pelajaran saja yaitu Bahasa Indonesia. Pada mata pelajaran Bahasa Indonesia terdapat empat keterampilan yang harus dikuasai oleh peserta didik, antara lain: keterampilan menyimak (listening skills), keterampilan berbicara (speaking skills), keterampilan membaca (reading skills), dan keterampilan menulis (writing skills). Pada penelitian ini hanya mengkaji satu keterampilan saja yaitu keterampilan menulis. Dimana ruang lingkupnya diperkecil lagi dengan mengkaji materi menulis karangan narasi pada tema 5 Pahlawanku Subtema 1 Perjuangan Para Pahlawan.

Sebelum melaksanakan penelitian, peneliti melakukan studi pendahuluan untuk mengetahui permasalahan yang ada, dan diperoleh informasi bahwa keterampilan menulis karangan mata pelajaran Bahasa Indonesia masih rendah, hal ini dibuktikan dengan ketika diberikan tugas untuk menulis karangan, siswa hanya menulis karangan seadanya, bahkan ada siswa yang hanya mampu menuliskan beberapa kalimat saja. 
Hasil wawancara dengan Bapak Arifin selaku guru kelas IV SD Negeri Peterongan menjelaskan bahwa siswa mengalami kesulitan dalam menemukan ide dan menuangkan gagasan ke dalam tulisan itu disebabkan karena kurangnya stimulus untuk siswa. Siswa kelas IV SD Negeri Peterongan lebih senang belajar keterampilan menulis karangan narasi menggunakan media gambar, video, atau suara. Dengan media tersebut akan mudah mendapatkan perhatian siswa untuk belajar menulis karangan narasi. Siswa menjadi lebih aktif dan berpartisipasi menganalisis gambar yang disajikan karena siswa berhasil mendapatkan stimulus yang membuat siswa nyaman seperti sedang bermain dan tidak merasa cepat bosan.

Kesulitan lain yang dihadapi siswa kelas IV SD Negeri Peterongan yaitu seputar tema. Siswa kesulitan membayangkan tema atau judul cerita yang tidak berkaitan dengan kehidupan sehari-hari seperti tema pahlawan, karena siswa akan sulit membayangkan dan merangkai kata-kata. Kesulitan tersebut bisa diatasi dengan pengguna model pembelajaran yang variatif dan media pembelajaran yang berwarna agar menarik perhatian siswa.

Masih banyak guru di SD Negeri Peterongan yang kurang menggunakan media pembelajaran yang interaktif. Tidak sedikit dari mereka yang merasa kerepotan untuk menyiapkan sebuah media pembelajaran yang variatif dan komunikatif, sehingga guru di SD Negeri Peterongan sering kali hanya memanfaatkan LCD proyektor sebagai media pembelajaran untuk menunjukkan materi Pembelajaran melalu Power Point.

Guru di SD

Negeri Peterongan sudah tidak muda lagi sehingga lebih senang mencari media pembelajaran yang simpel dan mudah didapatkan. Guru di SD Negeri Peterongan akan merasa terbantu kalau ada media pembelajaran yang simpel dan mudah didapatkan tetapi bersifat interaktif dalam pembelajaran sehingga akan melibatkan partisipasi aktif dari anakanak.

Penggunaan model pembelajaran yang inovatif juga belum diterapkan di SD Negeri Peterongan. Guru di SD Negeri Peterongan masih menggunakan metode lama yaitu metode ceramah. Alasannya karena menurut guru di SD Negeri Peterongan apa yang dilakukannya selama ini dalam kegiatan belajar mengajar dirasa sudah benar dan membantu menambah pemahaman anak-anak sehingga belum perlu menggunakan model pembelajaran yang inovatif dan media pembelajaran yang komunikatif dalam proses belajar mengajar.

Peneliti melanjutkan dengan membuat instrumen soal mata pelajaran Bahasa Indonesia dengan tema 5 Pahlawanku Subtema 1 Perjuangan Para Pahlawan khususnya materi keterampilan menulis karangan narasi. Instrumen soal tersebut kemudian diujikan pada kelas IV SD Negeri Peterongan sebagai soal Pretest dan Posttest.

Sebelum mengajar peneliti membagikan angket kepada siswa untuk diisi mengenai seberapa sukanya menulis karangan dan bagaimana cara guru mengajarkan materi menulis kerangan. Dari angket tersebut diketahui bahwa hanya sedikit siswa yang senang menulis karangan. Kebanyakan siswa merasa bosan dan bingung dengan apa yang akan dituliskan sehingga membuat siswa merasa pusing dan malas untuk menulis sebuah karangan. Hal tersebut juga dipengaruhi oleh cara mengajar guru yang hanya menggunakan model ceramah saja sehingga siswa kurang memiliki gambaran tentang apa yang akan dituliskannya.

Siswa kelas IV SD Negeri Peterongan belum menyadari tujuan dari menulis. Ditinjau dari kepentingan, menulis memiliki 6 tujuan antara lain tujuan penugasan, tujuan estetis, tujuan penerangan, tujuan pernyataan diri, tujuan kreatif, dan tujuan konsumtif. Materi menulis karangan narasi pada kelas IV masuk ke dalam tujuan penugasaan karena siswa menulis untuk memenuhi tugas yang diberikan oleh guru atau sebuah lembaga.

Peneliti melaksanakan penelitian di kelas IV SD Negeri Peterongan sebanyak tiga kali pertemuan pembelajaran di kelas.

Hari pertama pembelajaran, peneliti melakukan pretest dengan menunjukkan sebuah gambar seorang anak lelaki yang menolong seorang kakek banyak siswa yang merasa kesulitan dalam menuliskan gagasan ke dalam bentuk karangan narasi. Hal tersebut dikarenakan kurangnya minat belajar menulis karangan narasi pada siswa. Tidak ada motivasi menulis semakin membuat siswa tidak tahu apa yang akan ditulis ke dalam bentuk 
karangan narasi. Sebuah gambar saja ternyata kurang menjadi stimulus yang baik karena siswa masih pasif dalam proses pembelajaran, sehingga diperlukan stimulus yang mampu menarik perhatian siswa dan membuat siswa aktif berpartisipasi dalam pembelajaran.

Proses pembelajaran yang selama ini dilakukan di SD Negeri Peterongan seringnya menggunakan model pembelajaran konvensional atau model ceramah. Kebiasaan yang dilakukan terus-menerus ini berdampak pada siswa malas untuk berfikir kritis dan kreatif. Proses pembelajaran hanya berfokus pada guru yang menyebabkan siswa kurang aktif dalam proses pembelajaran yang berlangsung. Perhatian siswa akan teralihkan ke yang lain seperti mengobrol dengan teman atau bermain dengan teman dan menyebabkan siswa kurang paham akan materi yang diajarkan.

Pada hari kedua, partisipasi aktif mulai ditunjukkan siswa karena peneliti memberikan tugas melengkapi peta pikiran yang sudah didesain semenarik mungkin. Desain menarik peta fikiran di fungsikan sebagai stimulus untuk memancing kreatifitas siswa dan berhasil menarik perhatian serta minat menulis siswa sehingga siswa dengan antusias melengkapi peta pikiran tersebut. Dengan tugas tersebut siswa merasa belajar sambil bermain yang membuat peta pikiran terlengkapi dengan waktu yang tidak lama.

Kondisi siswa yang ditunjukkan pada hari kedua sesuai dengan pendapat Miftahul Huda (2013: 317) bahwa model pembelajaran Concept Sentence memiliki kelebihan antara lain meningkatkan semangat belajar siswa karena terciptanya suasana belajar yang kondusif dengan demikian memunculkan kegembiraan dalam belajar. Selain itu model pembelajaran Concept Sentence mendorong dan mengembangkan proses siswa berpikir kreatif untuk memandang sesuatu dalam pandangan yang berbeda. Hal inilah yang mendorong siswa mengerjakan tugas pada hari kedua dan ketiga lebih semangat dan hasil karangan siswa lebih baik dibandingkan sebelum diberi perlakuan.

Hari ketiga pembelajaran, dengan bantuan media pembelajaran Puzzle diawali dengan mengajak siswa bermain melengkapi puzzle terlebih dahulu membuat siswa merasa penasaran, tertantang, dan bertanya-tanya akan jadi seperti apa. Sehingga meningkatkan minat dan motivasi belajar siswa. Pembelajaran dengan menggunakan model Concept Sentence berbantu media Puzzle membuat siswa mudah mengerti urutan alur cerita yang benar dari Pangeran Diponegoro.

\section{Simpulan dan Saran}

Model pembelajaran Concept Sentence berbantu media puzzle berpengaruh terhadap meningkatkan keterampilan menulis siswa kelas IV SD Negeri Peterongan. Hal ini dibuktikan dengan banyak siswa yang mendapat nilai diatas KKM yang telah ditentukan. Selain itu, pada uji hipotesis diperoleh nilai rata-rata pretest sebanyak 65,6 dan nilai rata-rata posttest sebanyak 82,6 bahwa nilai posttest lebih tinggi dibandingkan dengan nilai pretest, kemudian dilakukan uji-t diperoleh perbedaan rata-rata nilai pretest dan posttest sebesar 17 dan thitung = 33,14 dengan db $\mathrm{N}=30-1=29$ dengan taraf signifikansi 0,05 sebesar 2,045.

Karena thitung $>$ ttabel maka $\mathrm{HO}$ diterima sehingga dapat disimpulkan bahwa "Model pembelajaran Concept Sentence berbantu media pembelajaran Puzzle berpengaruh terhadap keterampilan menulis karangan narasi siswa kelas IV SD Negeri Peterongan tahun pelajaran 2018/2019."

Saran dari hasil penelitian, saran yang dapat diajukan adalah guru dapat menjadikan alternatif dan mempertimbangkan penggunaan model pembelajaran Concept Sentence berbantu media puzzle dalam meningkatkan keterampilan menulis pada mata pelajaran Bahasa Indonesia, karena model pembelajaran ini mampu menarik perhatian siswa dan membuat siswa berfikir kritis dan kreatif dalam menganalisis gambar. Guru dapat mengembangkan mode pembelajaran Concept Sentence berbantu media puzzle dengan teknik atau model pembelajaran lainnya sesuai dengan kebutuhan materi dan karakteristik siswa. Bagi pembaca, penulis merekomendasikan model pembelajaran Concept Sentence berbantu media puzzle untuk diterapkan pada pembelajaran siswa Sekolah Dasar, karena model pembelajaran ini mampu menciptakan pembelajaran yang menyenangkan, mendapat 
partisipasi aktif dari siswa, dan dapat menciptakan imajinasi kreatif siswa sesuai dengan gambar puzzle yang ditampilkan.

\section{Daftar Pustaka}

Arikunto, Suharsini. 2006. Prosedur Penelitian Suatu Pendekatan Praktik. Jakarta: PT. Rineka Cipta

Arsyad, Azhar, Asfah Rahman. 2016. Media Pembelajaran. Depok: Rajagrafindo Persada

Dalman. 2016. Keterampilan Menulis. Jakarta: Rajawali Pers

Huda, Miftahul. 2013. Model-model Pengajaran dan Pembelajaran. Jakarta : Pustaka Pelajar

Shoimin, Aris. 2017. 68 Model Pembelajaran Inovatif dalam Kurikulum 2013. Yogyakarta: ArRuzz Media

Sugiyono. 2017. Metode Penelitian Pendidikan. Bandung: Alfabeta.

Sugiyono. 2015. Statistika Untuk Penelitian. Bandung: Alfabeta

Sumerti, Ni Luh. Pengaruh Model Pembelajaran Kooperatif tipe Concept sentence berbantuan Gambar berseri Terhadap Keterampilan Menulis siswa Kelas V SDN 22 Dauh Puri. MIMBAR PGSD Undiksha, 2014, 2.1.

Undang-Undang Nomor 20 Tahun 2003 tentang Sistem Pendidikan Nasional

Utami, Tri Yogi. Penerapan Model Concept Sentence Dengan Berbantuan Media Puzzel dalam Peningkatan Keterampilan Menulis Karangan Pada Siswa Kelas IV SDNCandiwulan Tahun Ajaran 2015/2016. Kalam Cendekia PGSD Kebumen, 2016, 4.2.1.

Wiarto, Giri. 2016. Media Pembelajaran Dalam Pendidikan Jasmani. Yogyakarta: Laksitas.

Widarso, Wishnubroto. 2006. Kiat Menulis dalam Bahasa Inggris. Yogyakarta: Kanisius

Yuliantini, Y, Halidjah, S., \& marli, S. Pengaruh Model Concept Sentence Terhadap Keterampilan Menulis karangan Deskripsi berbantuan Gambar Di Sekolah dasar. Jurnal pendidikan dan Pembelajaran, 7.8. 